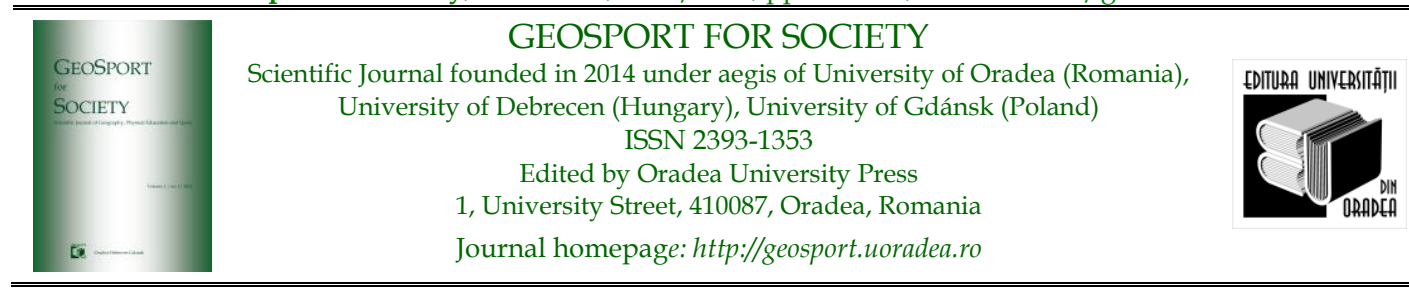

\title{
The Effect of Workplace Incentives with Regards to the Well-Being of the Employees
}

\author{
Anikó MOLNÁR*, Anetta MÜLLER
}

1. University of Debrecen, Department of Sports Management, Faculty of Economics and Business, Böszörményi, Debrecen, Hungary, e-mails: miller.e.annie@gmail.com, muller.anette@econ.unideb.hu

* Corresponding author

Citation: Molnár, A., \& Müller, A. (2020). The Effect of Workplace Incentives with Regards to the Well-Being of the Employees. Geosport for Society, 13(2), 108-122. https://doi.org/10.30892/gss.1302-064

Article history: 25.08.2020; Revised: 27.09.2020; Accepted: 06.11.2020, Available online: 14.11.2020

\begin{abstract}
Nowadays, health is not only valued for the individual, but many jobs have recognized that a healthy workforce contributes to a company's productivity and reduces health care costs, meaning that the value of human resources is an important pillar of the competitiveness of businesses and organizations (Nyitrainé Garaj, 2015; Péter, 2018; Bácsné et al., 2017). The main focus of our research was to examine the effect of incentives used in workplace health promotion on the well-being of the employees and on promoting healthy lifestyle. The data for our primary research was collected via questionnaire. The survey has been designed to provide information about the lifestyle of the average Hungarian employees, the fringe benefits as the incentives of physical activity and their utilization. Beyond this we were interested in finding out if there should be an initiation on the employers' side regarding physical activity would there be an inclination within the employees for its usage. The result of the survey $(\mathrm{N}=133)$ shows that since white collar workers spend the majority of their days with little to no physical activity while working, sough out more sporting activities outside work. The data also suggest a health conscious behaviour among the respondents with high scoring driving factors for physical activity such as the importance of health, stress relief etc. Furthermore, results showed that after receiving these incentives employees engaged more frequently in sporting activities and that there is a willingness for use among those not receiving it.
\end{abstract}

Keywords: workplace heath promotion, well-being, employee's well-being, healthy lifestyle

\section{Introduction}

In today's fast globalizing world where technological changes are constant the increasing need for effectiveness and comfortability outweighs the importance of physical activity. In addition, time spent with work is steadily growing. The number of working hours per week and the length of active working life have increased as well (Bokor, 2009). This change in lifestyle contributes significantly to the fast spreading of civilizational diseases. Because of this reason it is not surprising that 
the determining factor of future's competitiveness is considered to be healthy labour (Nyitrainé Garaj, 2015; Szolnoki, 2013; Hegyesné Görgényi, 2019).

The contribution of a healthy workforce can be interpreted on different levels. On one hand healthy employee has a direct impact on its organisation by lowering the cost of healthcare. Indirectly, the improvement of the workers health, absenteeism or days spent in sick leave and incapacity to work can be significantly lowered, while productivity is notably increased (Kapás, 2007).

Besides the direct and indirect impact on organisational efficiency it is important to mention other additional benefits of the healthy human capital and well-being of the employees', such as its impact on recruitment, retention, work moral, fluctuation, loyalty and the reputation or image of the organisation (Kapás, 2007). In conclusion healthy labour is a remuneratory investment in the business sector (Balogh, 2018).

Taken these facts into consideration it is not surprising that workplace health promotion, aimed at the physical and mental wellbeing of the employees is shifting more and more into focus in recent years and that it gives an integral part of European Union 2014-2020 strategy. European Agency for Safety and Health at Work has therefore given high priority to the issue as well (Bögös, 2018).

It is also important to mention, that while the general view is that physical wellbeing is the sole responsibility of the people, because the contribution of the individual and because its increased significance on organisation level highlighted above the role of the employer on health promotion can't be overlooked (Balogh, 2018; Hegyesné Görgényi, 2018; Karoliny, 2016).

The main focus of our research was to examine the effect of incentives used in workplace health promotion on the well-being of the employees and on promoting healthy lifestyle. The survey has been designed to provide information about the lifestyle of the average Hungarian employees, the fringe benefits as the incentives of physical activity and their utilization. Beyond this we were interested in finding out if there should be an initiation on the employers' side regarding physical activity would there be an inclination within the employees for its usage.

We have chosen two of these incentives from Hungarian health promotion practices, namely the "Szép" Card and the All You Can Move Sport Pass (AYCM). Where the former is a Card system containing three "pockets" with different amount of money in each that can be used up for accommodations, holidays, catering or health and sporting purposes as well. While the latter serve - as its name suggests as an ultimate Sport Pass that depending on the size of the package gives access of hundreds of sporting facilities country wide including yoga studios, swimming pools, gyms etc. to its owner.

\section{Theoretical background}

The positive effect of physical activity and exercise on health has already been proven (Lee et al., 2001; Biró, 2015; Hidvégi et al., 2017), but we can also find more and more research on individual sports and forms of movement. They analyze the effect of physical activity on the body, physical and mental health (Bond et al., 2002; 
Pikó and Keresztes, 2007; Borbély and Müller, 2008; Bodolai et al., 2016), and also deal with their recreational role (Bendíková, 2017; Puskás et al., 2018; 2019).

Active lifestyle, regular sporting activities becoming lifestyle elements and encouraging it in all ages is an important task, as they play an important role in the prevention of lifestyle related diseases (stroke, cardiovascular diseases, stress and mental illness, obesity, osteoporosis, cancer type 2 diabetes) (Borbély and Müller, 2008; Lakó, 2014; Müller and Bácsné, 2018, Kinczel et al., 2020).

With the majority of time spent with work, and its steady rise suggests that worksite importance shouldn't be overlooked and that it should be the place where change can and should be made. Besides its convenience coming from the long hours spent there the importance of healthy workforce is a long standing truth among scholars (Katzmarzyk and Janssen, 2004; Oldridge, 2008; Medibank, 2007; Karoliny, 2016).

It is also important to take into consideration the remuneratory attribution of workplace health promotion (Balogh, 2018). Baicker et al., (2010) estimated that for every dollar an American company spent on health promotion leads to the saving of 3.27 dollar healthcare cost and 2,73 on sickday leave.

That is why a great deal of literature today deals with occupational health and workplace health promotion. Based on this fact, many studies focus on health conscious corporate behaviour (Péter et al., 2013, Karoliny, 2016) or occupational health research (Kun, 2014) and the competitive advantage coming from having healthy workforce (Nyitrainé Garaj, 2015; Szolnoki, 2013; Hegyesné Görgényi, 2018).

Workers 'health is affected by stress, sedentary work, persistent loads, carrying heavy objects, environmental factors and social impacts (Nistor et al., 2015). The health status of employees can be adversely affected by high levels of stress, which can be caused by time constraints, unclear goals, and so on. Numerous studies also address workplace stress and its negative effects both on the employee and on the company as well (Calnan et al., 2001; Juhász, 2002; Olofsson et al., 2003; Lambert et al., 2003; Haffner and Bárdos, 2019).

Companies that promote health program experienced that absences due to illness have lowered, while they perceived a positive shift in their productivity. It should also be mentioned that the staff turnover or fluctuation of these companies also decreased while their image and reputation improved (Fritz, 2011).

In Hungary, several studies shed light on various health problems or risk factors caused by jobs, work tasks and working conditions (Hidvégi and Müller, 2009). The publication of a Hungarian study (Hidvégi et al., 2017) suggests physical activity and exercise based lifestyle programs in occupational health promotion, which can be an excellent means of compensating for sedentary work. Hartfiel et al., 2011 describes the positive effect of yoga on workers, one of the benefits of which was the stress relieving effect.

Bácsné et al., (2017) found that Hungarian, non multinational companies are already they realized that it was worth paying attention and money to the health of their employees. Most of the small and medium sized enterprises involved in their research, to some extent attention pay for your health. This is reflected in the fact 
that even for the use of a sports facility, they even give their employees a sports lease, and some of them are held annually also organizes a bypass sports event.

Research among several international employees has shown that in increase the physical activity of the workers and their sporting activities, health programs focusing on helping the workers to be more physically active with longer term planning are more successful (Skogstad et al., 2018; Corbett et al., 2018). Although workplace sports are also important, the positive effect of such sports activity in improving the long term physical activity results of employees has been demonstrated which was performed several times a week by the employees outside the workplace (Burn et al., 2017; Makai, 2019).

In addition to motivation, this type of fringe benefit can also result in satisfaction and loyalty to the company, as many studies show that life satisfaction in athletes is higher (Hidvégi and Müller, 2009b).

\section{All You Can Move Sport Pass (AYCM) and "Szép” Card as good practices of health incentives}

The ALL YOU CAN MOVE Sport Pass is an employer benefit solution, which provides the employees of the partner companies access to hundreds of AYCM facilities, like gyms, swimming pools, dance studios, etc. The Sport Pass can be used daily, even every day in different AYCM facilities available in the chosen package (all-youcanmove.hu, 2020).

In 1999 the distributing company of the so called AYCM, the "Klub Rekreáció Sport és Rendezvényszervező Iroda" was established. In this year the company created its first product, the predecessor of the AYCM, the "Rekreációs Kártya" (Recreational Card). The main purpose of the Card was, to face the HR challenges of the $21^{\text {st }}$ century, with offering their clients unlimited access to sports facilities like fitness clubs, swimming pools, saunas and others (allyoucanmove.hu, 2020).

Up until 2019 the company counts more than 850 sports facilities where they accept the Sport Pass, while more than 1,200 medium and large enterprises and government organizations provide AYCM Sport Pass to their employees (allyoucanmove.hu, 2020).

There are 6 main packages in the program from size " $S$ " to size "XXL" with differences in costs and the amount of accessible AYCM facilities with the Card.

Two payment methods can be chosen: Monthly payment or payment in sum. Beyond this the company offers three types of payment constructions for their clients (allyoucanmove.hu, 2020):

1. Co-Payment or Co-Financing: "where the employer can choose to pay a part of the Employee's AYCM Sport Pass - reaching maximum employee satisfaction. Giving as a fringe benefit (Tax Contribution is equal to the wage), through talent management or corporate wellness program, the employer is paying one part or the whole price of the AYCM Sport Pass."

2. Full-Payment: "this option is for those, who would like to finance the employees' AYCM Sport Pass completely, reaching the maximum employees' satisfaction - on this field. The employer concludes an Engagement Agreement with 
the AYCM, and the financial settlement of the cards will be made between the two companies (Tax Contribution is equal to the wage as well)."

3. Self-Payment: "where the employer concludes a Framework Agreement with the AYCM and agrees to announce the AYCM Sport Pass within its employees. The employees can individually decide if they would like to apply to the AYCM Sport Pass program, what package he/she needs and what payment method he/she would like to choose. In this construction the employer doesn't have any payment or administration obligation the employees will pay the AYCM Sport Pass individually from their salary or with OTP Cafeteria card - Gift subaccount."

A for the "Szép" Card, the "Széchenyi Pihenő" Card (Translation: Széchenyi Leisure Card) is a universal electronic voucher in Card format, which employees can receive from their employer as a fringe benefit within the cafeteria system. The main idea was to develop a benefit card system that helps the domestic economy recovery (szepkartyasok.hu, 2020).

The Card contains three subaccounts or "pockets" with different money limits. The biggest of the three is the accommodation pocket with 225000 HUF, which can be used up for domestic accommodations, domestic travels or holidays. The annual limit of the second pocket is 150000 HUF. Employees can pay with it for catering, warm dining in restaurants, canteens, buffays etc. And the third and smallest one with $75000 \mathrm{HUF}$ is the recreational pocket, which can be used up to pay in cultural and entertainment institutes or for sporting and health services (szepkart-yasok.hu, 2020).The amount transferred to the card is received in full by the employee, and can be used up full as well (szepkartyasok.hu, 2020).

\section{Material and methods}

The main focus of our research was to examine the effect of incentives used in workplace health promotion on the well-being of the employees and on promoting healthy lifestyle. The data for our primary research was collected via questionnaires. The questionnaire has been designed to provide information about the lifestyle of the average Hungarian employees, the fringe benefits as the incentives of physical activity and their utilization. Beyond this we were interested in finding out if there should be an initiation on the employers' side regarding physical activity would there be an inclination within the employees for its usage.

As we were particularly interested in the workplace habits of the respondents and their inclinations to workplace health incentives the questionnaires were filled out within the working strata, both on paper and online, using Google Survey platform.

The operative work was carried out using the IBM SPSS statistical data analysis program, in which descriptive statistical analyzes dominate (mean, standard deviation, median, mode).

The survey was created containing open and close ended, short answer questions. Besides this Likert scale (from 1 to 5) questions were generated in order to gather information what drives respondents to participate in sporting activities, how much these incentives affected the attitudes to the employees towards their employers. 
In addition to descriptive statistics, we have used the Chi-square cross table test to determine the relationship between the nature of the employees' work and their habits regarding physical activity.

To evaluate the effect of these incentives on the sporting habit of worker's, among Card holders we have compared the frequency of participating in physical activities before and after obtaining any of the Card.

\section{Introducing the sample}

During the data collecting we've received 150 surveys both on paper and on the on line platform - from which after the data cleaning 133 were used. After analyzing the evaluable questionnaires we've received the following sociodemographic picture of the respondents.

Out of the 133 fill outs $53.4 \%$ of them (71 people) were made by women and $46.6 \%$, or 62 , were made by men, with an average age of 33.3 years (standard deviation 10.4). As the theme of our research suggests our main target group was the working strata. The age of our youngest respondent was $20 \mathrm{yrs}$, and the oldest $61 \mathrm{yrs}$.

As for the highest level of the education, with $59.8 \%$ (79 people) the majority of our respondents have high school (gymnasium, technical school, vocational school) qualification; $20.3 \%$ (27 people) have university degree; $19.5 \%$ (26 people) have collage degree, and one person $(0.8 \%)$ has elementary school qualification as the highest level of education.

One of the more important questions was the nature of the respondents work. Are they white collar workers, or physical workers or even both? After evaluating the answers the following statistics were compiled (Table 2).

Table 1. The nature of the respondents work Source: Own research (2020)

\begin{tabular}{|l|c|c|}
\hline & $\begin{array}{c}\text { Frequency } \\
\text { (Persons) }\end{array}$ & $\begin{array}{c}\text { Percent } \\
\text { (\%) }\end{array}$ \\
\hline Physical work & 20 & 15 \\
\hline Mental work & 83 & 62.4 \\
\hline Both & 30 & 22.6 \\
\hline Total & 133 & 100 \\
\hline
\end{tabular}

As Table 1, above shows the majority of the respondents (62.4\%) are white collar workers while only $37.6 \%$ of them does physical work with some kind of intensity. This means that our target group spends the majority of their days with little to no physical activity while working. The fact that the greater part of those participating in the survey are doing mental work advantageous result, because the effect of workplace health incentives can be analyzed more effectively among employees with sedentary lifestyle.

In addition to this we have asked them to estimate the net value of their monthly salary and if they possess any one of the Cards mentioned above. 
As the left diagram of Figure 1 shows the majority of those questioned have either Szép Card, AYCM Sport Pass or both (Cumulative percentage is 60.9\%), while $39.1 \%$ neither. Based on these answers, for further analyzation the respondents were broken down into two groups, where in the group holding Cards we are examining the usage, motivations and its impact on lifestyle and on the attitude towards the employers. While in the other one question are asked regarding their willingness, so as to would they take up on the opportunity if such incentives were introduced by their employers
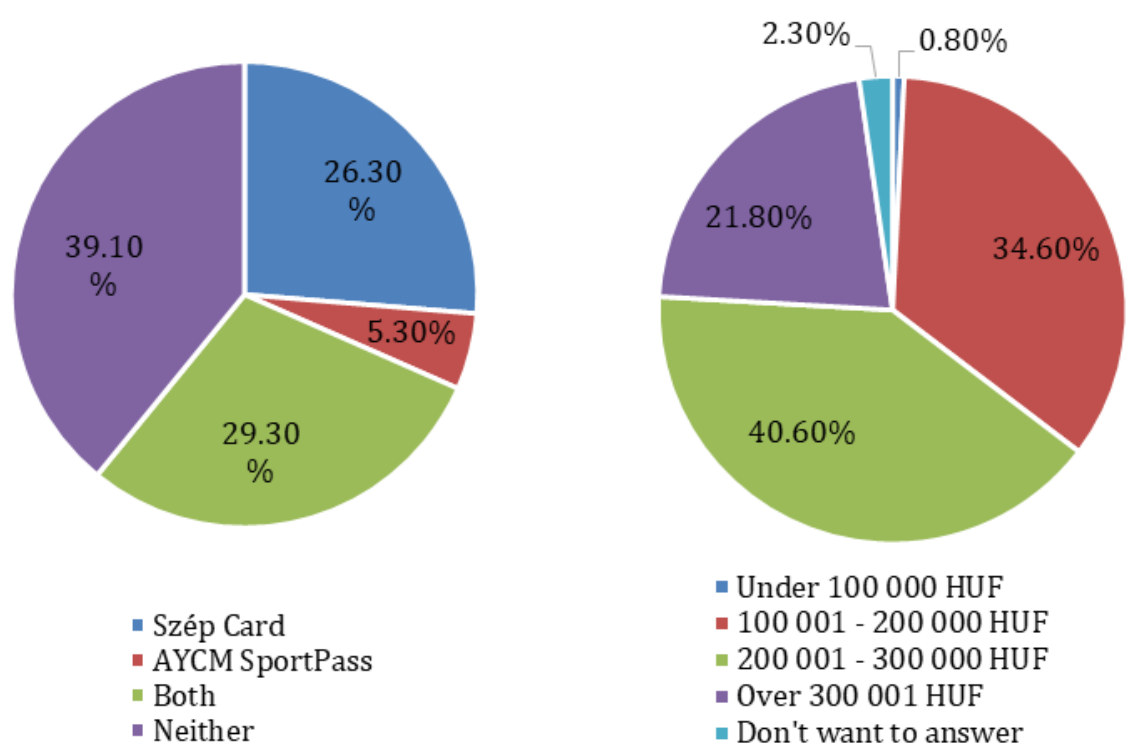

Figure 1. The Card possession and income situation of the respondents Source: Own research (2020)

From the 133 , three people $(0.8 \%)$ opted out of answering question about their monthly income. Among those willing to answer the majority (40.6\%) estimated the net value of their monthly income between 200001 and 300000 HUF ( 1 Euro $=$ around 354 HUF as of 05.01.2020). The second greatest strata earns between 100000 and 200001 HUF, while those earning over 300001 HUF represented $21.8 \%$ of the group.

Because the use of Szép Card is not restricted to sports or health purposes only we have created a question to see if respondents have any sport or health related spendings with this type of card.

From 81 Szép Card holders relatively small percent uses the Card for this purpose (Table 2). It is not surprising however, since the Leisure pocket, which can be used for this reason is the smallest of three and because the other two pockets are more desirable, since they can be used for accommodations and holidays or catering and warm dining. Besides this employers can decide if they want to manage the allocations of the pockets so this can be more restricted or they can entrust it to their employees. 
Table 2. The utilization of Szép Card regarding heath or sport related spendings Source: Own research (2020)

\begin{tabular}{|l|c|c|}
\hline & $\begin{array}{c}\text { Frequency } \\
\text { (Persons) }\end{array}$ & $\begin{array}{c}\text { Percent } \\
(\%)\end{array}$ \\
\hline Sport purpose spending & 9 & 11.1 \\
\hline Health purpose spending & 12 & 14.8 \\
\hline Both & 12 & 14.8 \\
\hline Neither & 48 & 59.3 \\
\hline Total & 81 & 100 \\
\hline
\end{tabular}

\section{Results of the correlation tests}

For us to get a basic picture about the sporting habits of the employees especially considering the nature of their work we have taken a Chi2 test to see whether the type of work they do affects their physical activity (Figure 2).

\section{Do you participate in any type of sporting activity? ${ }^{*}$ The nature of your work? Crosstabulation}

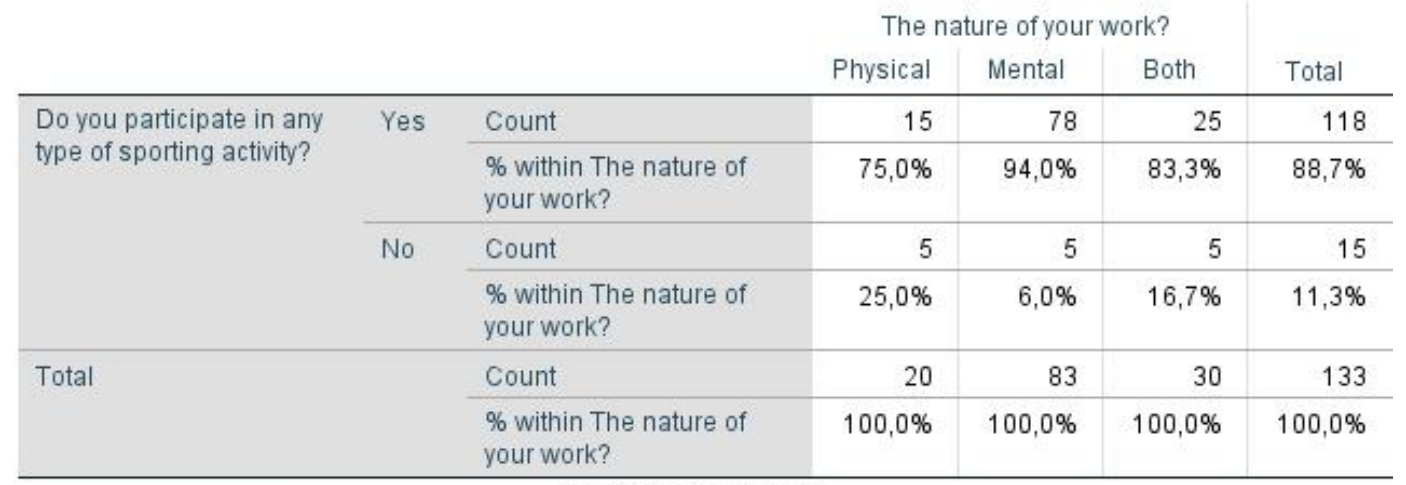

\section{Chi-Square Tests}

\begin{tabular}{|c|c|c|c|}
\hline & Value & df & $\begin{array}{l}\text { Asymptotic } \\
\text { Significance } \\
\text { (2-sided) }\end{array}$ \\
\hline Pearson Chi-Square & $6,924^{a}$ & 2 & 031 \\
\hline Likelihood Ratio & 6,396 & 2 &, 041 \\
\hline $\begin{array}{l}\text { Linear-by-Linear } \\
\text { Association }\end{array}$ &, 256 & 1 &, 613 \\
\hline $\mathrm{N}$ of Valid Cases & 133 & & \\
\hline
\end{tabular}

Figure 2. The Card possession and income situation of the respondents Source: Own research (2020)

For the question: "Do you participate in any type of sporting activities?" 75\% of the physical workers answered with yes. From those who have both physical and intellectual work $83.3 \%$ chose yes, while $94 \%$ of the white collar workers said they 
participate in sporting activities with some kind of intensity. The results showed significant differences between the respondents regarding the nature of their work (Chi2=6.92, df=2, p=0.031).

Research has shown that the physical activity of those performing mental work is significantly higher than that of those performing mixed or physical work. This finding is important because we can conclude that white collar workers sought recreational sports to compensate for sedentary and inactive work. The lower percentage of participation among physical workers is due to the fact that it is true that physical workers are more active, but it is important to note that the activity spent at work is not a substitute for the beneficial effects of sport on the body.

Since white collar workers are clearly favor physical activities outside work and actively soughing it and engaging in it employers should take up on the opportunity and assist it, moreover they should encourage it, considering the positive effect it has on productivity, competitiveness and its cost reducing quality.

\section{Results}

First, we wanted to take look at what drives these employees to participate in sporting activities. For this reason, we have created a Likert scale question where respondents could rate the 10 statements from 1 to 5 where 1 means the respondent doesn't agree at all, while 5 means they fully agree with the statement.

Figure 3 below shows the collective results to this question.

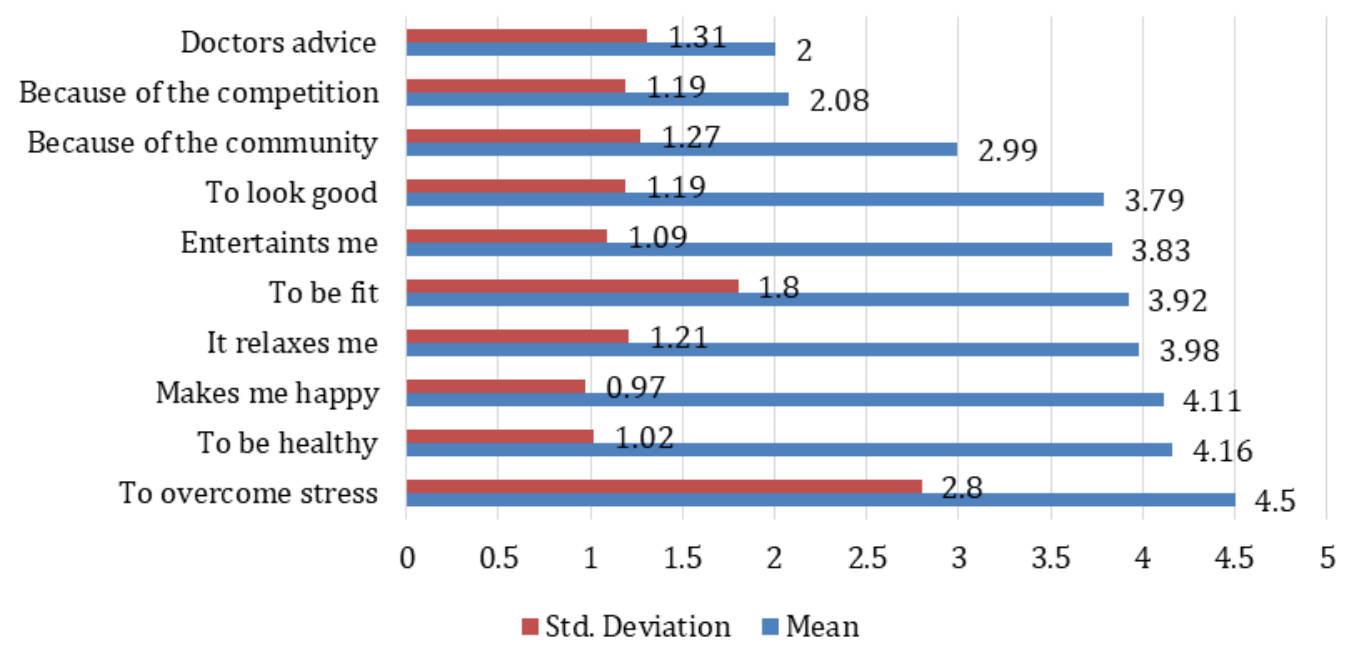

Figure 3. Why do respondents take part in sporting activities? (on a Likert scale from 1 to 5 where 1 means the respondent doesn't agree at all, while 5 means they fully agree with the statement) Source: Own research (2020)

With an average score of 4.5 from 5 , the highest rated statement is that employees are participating in physical activities to overcome stress. As the results shows respondents use physical activities as tools to help relieve stress, which is an important outcome considering the fact that workplace stress is a growing concern 
in today's fast globalizing and competitive economy (Van der Zwan et al., 2015). In addition to the impact stress have on ones well-being it has a great economical effect as well, since workplace induced stress can increase absenteeism; create pervasive dysfunctional pattern and lower productivity (Colligan and Higgins, 2006).

As the results indicates workers regard physical activity's stress relieving quality highest on the list. Because of this reason and the increasing seriousness of stress, employers should take into account to incite their employees to exercise more. This is a highly remuneratory investment and the consciousness of the respondents regarding Physical activity's effect indicates their willingness to take on the opportunity if it should be given.

The second highest rated statement, with an average score of 4.16 is linked to health as well. The health consciousness nature of employees' is clearly present among the respondents. This also indicates a positive attitude towards physical activities.

The statements "Makes me happy" (Avg. score: 4.11) "Relaxes me" (Avg. score: 3.98) which also relates back to the stress relieving attribution of physical activities scored third and fourth highest on the list.

In conclusion health conscious driving and motivating factors scored higher on this question while secondary attributions of sporting activities such as competition and the community ended up at the back. The conscious attitude of the employees is a positive result both from the standpoint of health development and both from willingness. Because this type of awareness suggests that there is a need among employees for this type of incentives.

In order to evaluate the effect workplace health promotion incentives have on the habits of the employees we have asked them how often they participated in any kind of sporting activities and how did it change after using one. For this reason, the answers of those holding a Card $(\mathrm{N}=81)$ were analyzed with Paired Sample T Test, and the frequencies of the two question was presented graphically (Figure 4).

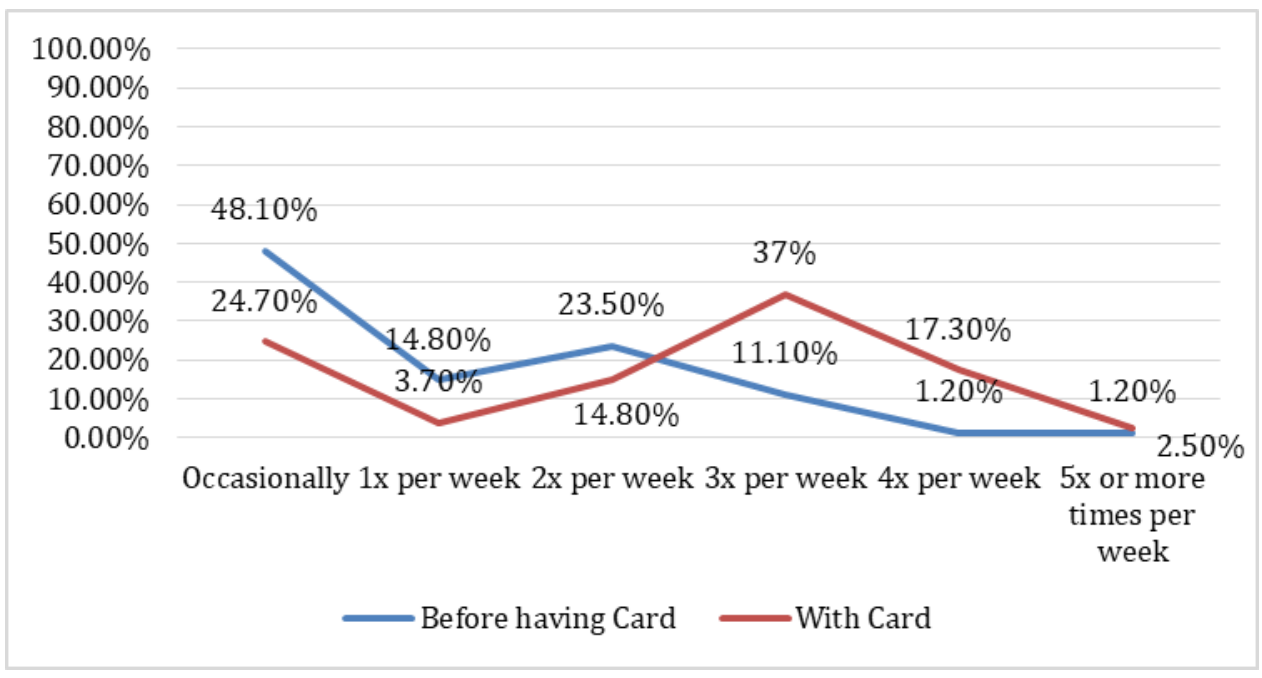

Figure 4. The intensity of sporting activities before owning a Card and after Source: Own research (2020) 
The results showed that before owning any type of Card the respondents took part in sporting activities with an average of $2.06(\mathrm{Sd}=1.22)$ times per week frequency, whilst after getting one and using it this amount increased to 3.26 $(\mathrm{Sd}=1.5)$ times per week $(\mathrm{t}=-7.09, \mathrm{df}=80, \mathrm{p}=0.000)$. The results therefore confirm that by using a Card employees participate in sporting activities significantly more than before owning one (Figure 4).

This outcome draws attention to the fact that the card can be a powerful motivating and incinting tool in increasing the sports activities of employees. And because physical activities improve health, it certainly shouldn't be overlooked. Furthermore, this results suggests that, given the significant contribution of a healthy workforce to organizational performance, productivity, competitiveness, the cost reducing quality of the employees' health and therefore the remuneratory nature of the investment makes workplace health promotion incentives, as fringe benefits for the employees a desirable construction in organization programs.

Amon those not having any type of the two studied Card $(\mathrm{N}=52)$ we were interested in finding out if there should be an initiation on the employers' side regarding physical activity incenting fringe benefits would there be an inclination within the employees for its usage.

For this reason we have created a Likert scale question, with the question "Would you participate more in any sporting activities if ...?" where respondents could rate from 1 to 5 where 1 indicated the respondent doesn't agreed at all, and 5 where they fully agreed with the statement

Table 3. Would you participate more frequently in any type of sporting activities if Source: Own research (2020)

\begin{tabular}{|l|c|c|}
\hline & $\begin{array}{c}\text { Frequency } \\
\text { (Persons) }\end{array}$ & $\begin{array}{c}\text { Percent } \\
(\%)\end{array}$ \\
\hline Don't agree at all & 7 & 13.5 \\
\hline Slightly agree & 2 & 3.8 \\
\hline Agree & 21 & 40.4 \\
\hline Strongly agree & 12 & 23.1 \\
\hline Fully agree & 10 & 19.2 \\
\hline Total & 52 & 100 \\
\hline
\end{tabular}

As Table 3 demonstrates from the 52 respondents who don't own a Card, only $13.5 \%$ is fully indifferent towards health promoting fringe benefits, while $86.5 \%$ percent showed inclination to it with some kind of intensity.

The positive result of $\mathrm{T}$ sample, and the willingness showed by those not receiving from this incentives shows that there is a clear need among employees regarding health promoting benefits from their employers, and that it is a utilized construction.

After finding out that there is a clear positive stance towards health promoting fringe benefits among both those receiving it and those of not, we were curious if it had any impact on attitude towards employers providing it. We have asked the 
respondents to rate that receiving these fringe benefits either improves the attitude towards their employers (question 1) or worsen it (question 2).

The overall sentiment of the respondents with an average score of 4.23 (Sd.= 1.2) out of 5 ( 1 indicated the respondent doesn't agreed at all, and 5 where they fully agreed with the statement) a positive attitude, which coincide the studied literature about the improvement of the company's image, reputation and loyalty to the employer, which helps with fluctuation and productivity as well. While question two that asked about whether it worsens the employees attitude showed a relatively low score 1.33 (Sd.=1.12).

The results highlighted that besides the positive direct effect in business sector, employers should invest in their employees health, as it is also improve the work moral and the employees attitude to their employers.

\section{Conclusion}

The research highlighted the differences caused by the employees' nature of work. The results showed that white collar workers engage more frequently in sporting activities outside their work than physical workers, since they spend the majority of their time with little to no physicals activities while working. They try to compensate this sedentary lifestyle, as they actively sough opportunities that offer physical activities. The lower percentage of participation among physical workers is due to the fact that it is true that physical workers are more active, but it is important to note that the activity spent at work is not a substitute for the beneficial effects of sport on the body.

The analyzations of motivating factors showed a health conscious attitude among the employees. With the highest scored driving factors regarding exercise: stress relieving and relaxing quality, healthy and fitness and of course its delighting effect. We assume that this type of awareness has a positive impact in the utilization of these incentives.

In order to evaluate the effect workplace health promoting fringe benefits have on the habits of the employees we have chosen two of these incentives from Hungarian health promotion practices, namely the "Szép" Card ( an electric voucher system with account that can be used for sport and health purposes) and the All You Can Move Sport Pass (AYCM) (an ultimate SportPass that makes hundreds of sporting facilities available for its owners with unlimited using time) and asked the respondents how often did they participate in any kind of sporting activities before owning one of these Cards and how did it change after using one. After analyzing the results, we can conclude that there is a positive significance. It showed that by using a Card, employees participate in sporting activities significantly more than before owning one.

And among those not having any type of the two studied Card we were interested in finding out if there should be an initiation on the employers' side regarding the encouragement for physical activity, would there be an inclination within the employees for its usage.

And since the results confirmed that there is a clear positive stance towards health promoting fringe benefits among both those receiving it and those of not, we were curious if it had any impact on attitude towards employers providing it. 
The outcome supported our previous assumptions. The overall sentiment of the respondents was that in fact it did improve the reputation of their employers and the company as well.

From the awareness and health conscious behavior of the employees', the significant effect it has on the frequency of physical activity engagement, the willingness of those who doesn't receive it and the positive impact it has on the reputation of the company it is clear that workplace health promotion incentives are working, it is a remuneratory investment, and because these facts employers should take up on the opportunity and use it for both their employees and their company' sake.

\section{Acknowledgement}

The publication is supported by the Debrecen Venture Catapult Program, EFOP-3.6.1-16-2016-00022 project. The project is cofinanced by the European Union and the European Social Fund.

\section{References}

AllYouCanMove.hu (2020). https://allyoucanmove.hu/aycm-sportpass/mi-az-aycm-sportpass, accessed: 2020.03.27.

Bácsné Bába É., Szabados, G., \& Madarász, T. (2017). Munkavállalók fizikai állapot felmérésének tapasztalatai a kkv szektorban. Taylor, 9(2), 179-187.

Baicker, K., Cutler, D., \& Song, Z. (2010). Workplace wellness programs can generate savings. Health affairs, 29(2), 304-311.

Balogh, R. (2018). The Role of Physical Activity in Workplace Health Promotion, In: „Movement For Health" The Importance Of Physical Activity In Health Protection Of Future Workers International Conference And Workshop Proceedings, pp. 99-106.

Bendíková, E. (2017). Theory of Health, Movements and lifestyle of Human Beings, Debrecen University Press, Debrecen, 164 p. ISBN: 978-963-473-219-8.

Biró, M. (2015). Current questions in Physical Education, In: Révész L., \&amp; Csányi T. (Ed.) Scientific Foundations for Teaching Physical Education Volume I: Excerpts from the Subjects of Physical Education, Exercise, and School Sports. Social, natural and medical perspectives. 286 p. Budapest: Hungarian Student Sports Association. pp. 105-136.

Bodolai, M., Lívják, E., Boda, E., \& Biró, M. (2016). The effect of yoga on the body, and its role in stress management. Acta Academiae Paedagogicae Agriensis Nova Series: Sectio Sport, 43, 51-67.

Bögös, T. (2018). Health Development In Workplace - Case Study On Good Practices Of A Bank, In: „Movement For Health" The Importance Of Physical Activity In Health Protection Of Future Workers International Conference And Workshop Proceedings, pp. 75-80.

Bokor, A. Szőts-Kováts, K., Csillag, S., Bácsi, K., \& Szilas, R. (2009). Human Resource management, Aula Press, Budapest.

Bond, D. S., Lyle, R. M., Tappe, M. K., Seehafer, R. S., \& D'Zurilla, T. J. (2002). Moderate aerobic exercise, T'ai Chi, and social problem-solving ability in relation to psychological stress. International Journal of Stress Management, 9(4), 329-343.

Borbély, A., Müller, A. (2008). Relationships and methodology of physical-mental harmony. Reality-Map6. PEM studies, Budapest, $211 \mathrm{p}$.

Burn, N., Norton, L. H., Drummond, C., \& Norton, K. I. (2017). Changes in Physical Activity Behaviour and Health Risk Factors Following a Randomised Controlled Pilot Workplace Exercise Intervention. AIMS public health, 4(2), 189-201.

Calnan, M., Wainwright, D., Forsythe, M., Wall, B., \& Almond, S. (2001). Mental health and stress in the workplace: the case of general practice in the UK. Social science \& medicine, 52(4), 499-507.

Colligan, T. W., \& Higgins, E. M. (2006). Workplace stress: Etiology and consequences. Journal of workplace behavioral health, 21(2), 89-97. 
Corbett, D. B., Fennell, C., Peroutky, K., Kingsley, J. D., \& Glickman, E. L. (2018). The effects of a 12-week worksite physical activity intervention on anthropometric indices, blood pressure indices, and plasma biomarkers of cardiovascular disease risk among university employees. BMC Research Notes, 11(1), 80.

Fritz, P. (2011). Recreation for Everyone Part I: Motion Recreation. Szeged, Bába Press, 469 p.

Haffner, 0., \& Bárdos, Gy. (2019). Manifestations of stress in job interviews and in the workplace. University of Pécs, Faculty of Humanities Periodic 10(1).

Hartfiel, N., Havenhand, J., Khalsa, S. B., Clarke, G., \& Krayer, A. (2011). The effectiveness of yoga for the improvement of well-being and resilience to stress in the workplace. Scandinavian journal of work, environment \& health, 70-76.

Hegyesiné Görgényi, É. (2019). The role of workplace health promotion in the company's internal CSR activities, 5th International Winter Conference of Doctoral Students and Researchers in Economics Proceedings.

Hidvégi, P., \& Müller, A. (2009a). Studies on workplace stress. Acta Academiae Paedagogicae Agriensis Nova Series: Sectio Sport, 36, 33-51.

Hidvégi, P., \& Müller, A. (2009b). Job satisfaction based on an empirical study of the staff of the Customs and Finance Guard and the teachers of the Vocational Secondary Schools. Aeronautical Science Publications, 21(4).

Hidvégi, P., Bíró, M., Müller, A., \& Váczi, P. (2017). Physical education program in workplace health development. Acta Academiae Paedagogicae Agriensis Nova Series: Sectio Sport, 44, 115-138.

Juhász, Á. (2002). Workplace Stress, Workplace Health Promotion, Budapest.

Kapás., Zs. (2007). Workplace health promotion as a remuneratory investment, National Institute for Health Development Recommendation.

Karoliny, M. (2016). Az egészségtudatos vállalati magatartás fejlesztésének diagnosztikai modellje. A diagnostic model for the development of health conscious corporate behavior). International Journal of Engineering and Management Sciences, 1(1), 1-18.

Katzmarzyk, P.T., \& Janssen, I. (2004). The economic costs associated with physical inactivity and obesity in Canada: an update. Canadian Journal of Applied Physiology, 29(1), 90-115.

Kinczel, A., Maklári, G., \& Müller, A. (2020). Recreational Activities and Motivation Among Young People. Geosport for Society, 12(1), 53-65.

Kun, A. (2014). Compensation for occupational health damage in Hungarian labor law - liability rules and compensation, $2 . \quad$ Hungarian Labor Law E-journal www.epa.oszk.hu/02500/02566/00001/pdf/EPA02566_magyar_munkajog_kun_091-119.pdf accessed: 2020.03.27.

Lakó, J. H. (2014). The issues of the relationship of grandparents and grandchildren in the light of physical activity. European Journal of Mental Health, 9(02), 178-194.

Lambert, V. A., Lambert, C. E., \& Yamase, H. (2003). Psychological hardiness, work-place stress and related stress reduction strategies. Nursing \& Health Sciences, 5(2), 181-184.

Lee, I. M., Rexrode, K.M., Cook, N.R., Hennekens, C.H., \& Buring, J.E. (2001). Physical activity and breast cancer risk: the Womens Health Study (United States). Cancer Causes \& Control, 12(2), 137-145.

Makai, A. (2019). Relationships between physical activity and socio-demographic characteristics of the adult population in the light of quantitative studies and a health program. Phd thesis, 2019, Pécs. $130 \mathrm{p}$. http://doktoriiskola.etk.pte.hu/public/upload/files/Doktoriiskola/Tezisfuzetek/Makai_Alexandra_ dissz.pdf accessed: 2020.03.27.

Medibank (2007). The cost of physical inactivity: what is the lack of participation in physical activity costing Australia. http://www.medibank.com.au/Client/Documents/Pdfs/pyhsical_inactivity.pdf accessed: 2020.03.27.

Müller, A., \& Bácsné, Bába É. (2018). The relationship between a healthy lifestyle and sport. Létavértes, Magyarország: Létavértes SC '97 Egyesület (2018), 96 p. ISBN: 9786150031897.

Nistor, K., Nistor, A., Ádám, S., Szabó, A., Konkolÿ Thege, B., \& Stauder, A. (2015). The relationship of work-related psychosocial risk factors with depressive symptoms among Hungarian workers: Preliminary results of the Hungarian Work Stress Survey. Medical Weekly, 156 (11), 439-448.

Nyitrainé Garaj, E. (2015): Competitiveness and health gains. Value creating alternatives to workplace health promotion. Military Sciences, 25, 41-47. 
Oldridge, N.B. (2008). Economic burden of physical inactivity: healthcare costs associated with cardiovascular disease. European Journal of Cardiovascular Prevention and Rehabilitation, 15(2), 130-139.

Olofsson, B., Bengtsson, C., \& Brink, E. (2003). Absence of response: a study of nurses' experience of stress in the workplace. Journal of nursing management, 11(5), 351-358.

Péter, E. (2018). Evaluation of factors influencing the motivation and efficiency of human resources. Multidisciplinary Challenges Diverse Answers, (Special Issue), 39-56.

Péter, E., Keller, K., \& Kaszás, N. (2013). Health Awareness - Part of Organizational Culture?. Budapest Management Review, 44(6).

Piko, B., \& Keresztes, N. (2007). Sport, mind, health. Akadémiai Press, Budapest.

Puskás, A. L., Bíró, M., Hídvégi, P., Molnár, A., Lente, L., \& Pucsok, J. M. (2019). Analysis of the North Great Plain Region's Accommodation Supply with Special Focus on Sport and Wellness Elements. Geosport for Society, 10(1), 15-24.

Puskás, A.L., Biró, M., Dobay, B., \& Pucsok, J.M. (2018). Analysis of the supply elements and services of leisure sports in the hotels of Hungary's Northern Great Plain region. Selye E-Studies, 9(1), 13-21.

Skogstad, M., Lunde, L. K., Ulvestad, B., Aass, H. C., Einarsdottir, E., Øvstebø, R., ... \& Skare, Ø. (2018). 1249 Improvements in biomarkers of inflammation and health after an employer-motivated leisure time physical activity program: a 15 month follow up study.

Szepkarytasok.hu (2020). http://www.szepkartyasok.hu/content/mi-az-szép-kártya accessed: 2020.03.27.

Szolnoki, B. (2013). On what extent does workplace health promotion can contribute to increasing individual performance?, Conference paper, https://www.researchgate.net/publication/327106445 accessed: 2020.03.27.

van der Zwan, J.E., de Vente, W., Huizink, A.C. (2015). Physical Activity, Mindfulness Meditation, or Heart Rate Variability Biofeedback for Stress Reduction: A Randomized Controlled Trial. Appl Psychophysiol Biofeedback 40, 257-268. https://doi.org/10.1007/s10484-015-9293-x 